lein) mający za sobą prawie 1500 lat historii pisanej, uświadamiamy sobie, że mamy wiele pomocy do studiowania zabytków literackich chrześcijaństwa gruzińskiego. Niechaj ten przyczynek zainspiruje kogoś chętnego do napisania gramatyki języka gruzińskiego również w języku polskim.

Jerzy Woźniak CM - Bydgoszcz, UAM

\title{
Christian Spirituality, vol. 1: Origins to the twelfth century, ed. B. McGinn - J. Meyendorff in collaboration with J. Leclercq, World Spirituality 16, New York 1985, ed. 2 - 2000, The Crossroad Publishing Company, ss. 502.
}

Recenzowana książka stanowi część serii zatytułowanej „Świat duchowości”. Autorzy i wydawcy tej serii starali się wyjść naprzeciw widocznemu pod koniec XX wieku trendowi zainteresowania duchowością i zauważalnemu zbliżeniu między Wschodem a Zachodem. Celem serii jest pomoc we wzajemnym zbliżeniu duchowości wywodzących się z różnych kultur. Zbliżenie to może dokonać się poprzez przekaz wiedzy o duchowości, którą należałoby uznać za najstarszą dyscyplinę historii.

W omawianym tomie dokonano prezentacji duchowości chrześcijańskiej od początków do XII wieku. Autorzy podejmują temat duchowości nie tylko w wymiarze ascetycznym i mistycznym, ale także wspólnotowym i socjologicznym. Uważają, że jest to zakres szerszy niż przedmiot dyscypliny nazywanej dzisiaj teologią duchowości, chociaż podkreślają równocześnie nierozerwalny związek duchowości chrześcijańskiej z teologią. Przyjmują założenie, że prezentacja winna mieć charakter ekumeniczny, co zaowocowało doborem autorów reprezentujących środowisko zarówno katolickie, jak i prawosławne i protestanckie.

Książka podzielona została na dwie części. Pierwsza część, zatytułowana: „Periods and Movements” stanowi chronologiczne ujęcie dziejów duchowości chrześcijańskiej od ok. 100 do 1200 roku. Przyjęcie jako górnej granicy starożytności wieku XII wychodzi niewątpliwie naprzeciw ujęciu protestanckiemu, które granicę tę przesuwa na okres późniejszy (1054 rok), niż to ma miejsce w ujęciu katolickim. Zdaniem autorów, uzasadnieniem takiego przyjęcia górnej granicy jest nie tylko ekumeniczny punkt widzenia, ale także fakt, że dzieła zachodnich mistrzów duchowości w XII wieku w większym stopniu zwrócone są ku chrześcijaństwu okresu patrystycznego, zarówno łacińskiego jak i greckiego, niż ku późniejszemu średniowieczu. Z tej przyczyny św. Bernard z Clairvaux bywa nazywany zarówno przez katolików jak i przez protestantów ostatnim z Ojców.

Część druga nosi tytuł: „Themes and Values” i stanowi zbiór artykułów tematycznych. Ich dobór był podyktowany możliwie najpełniejszym naświetle- 
niem życia duchowego chrześcijan w kontekście toczących się dyskusji teologicznych i wynikającym z nich wpływie lex credendi na lex orani.

Część pierwszą otwiera artykuł znanego teologa greckiego J.D. Zizioulasa nt. wczesnochrześcijańskiej wspólnoty („The Early Community”, ss. 23-43). Autor wyakcentował rolę nadziei eschatologicznej pierwszych chrześcijan w formowaniu ich duchowości, jak również rolę męczeństwa, które stało się wtedy swego rodzaju formą duchowości. Z kolei - trzymając się porządku chronologicznego - omówiona została duchowość gnostycka („Gnostic Spirituality", ss. 44-60). Wybitny znawca gnostycyzmu R.M. Grant opisuje praktyki ascetyczne gnostyków w różnych systemach gnostyckich i wykazuje ich wpływ na środowiska chrześcijańskie II wieku. Następny rozdział stanowi sumaryczne przedstawienie duchowego przesłania największych Ojców Kościoła: Atanazego, Kapadocczyków, Jana Chryzostoma, Hilarego, Ambrożego, Hieronima i Augustyna (Ch. Kannengiesser - „The Spiritual Message of the Great Fathers", ss. 61-80). Ich nauczanie pozostaje wspólnym patrimonium wszystkich chrześcijan. Światowej sławy specjalista zagadnień monastycyzmu J. Gribomont podejmuje się analizy ascezy mnichów na Wschodzie („Monasticism and Asceticism. I. Eastern Christianity", ss. 89-112), a J. Leclercq na Zachodzie („Monasticism and Asceticism. II. Western Christianity”, ss. 113-131). Z kolei Pseudo-Dionizy przedstawiony został jako teoretyk duchowości w późnej starożytności na Wschodzie, który formułując w kategoriach neoplatońskich reguły teologii mistycznej, wywarł wpływ na dalsze wieki (P. Rorem „The uplifting Spirituality od Pseudo-Dionysius, ss. 132-151).

Redaktorzy książki są świadomi tego, że duchowość wczesnego chrześcijaństwa była formowana nie tylko przez Ojców greckich i łacińskich, ale także przez wschodnich, szczególnie syryjskich. Temu zagadnieniu poświęcony zostaje następny rozdział, w którym wypunktowano najistotniejsze elementy chrześcijaństwa syryjskiego (R.C. Bondi - „Christianity and Cultural Diversity. I. The Spirituality of Syriac-speaking Christians”, ss. 152-162). Cenne dopełnienie tego poszerzonego spektrum stanowi omówienie duchowości ludów celtyckich i germańskich po przyjęciu przez nie chrześcijaństwa (P. Riché „Christianity and Cultural Diversity. II. Spirituality in Celtic and Germanic Society", ss. 163-176).

Problematyka duchowości w wiekach X-XI ujęta została w kontekście reformy gregoriańskiej, która - zmierzając do oczyszczenia Kościoła z dominacji świeckiej - starała się ukazać właściwe miejsce w Kościele dla poszczególnych jego członków (K.F. Morrison - „The Gregorian Reform”, ss. 177-192). Część pierwszą kończy rozdział nt. świata chrześcijańskiego w XII wieku („,The Religious World of the Twelfth Century”: B. McGinn - „Introduction”, ss. 194195; B. Ward - „Anselm of Canterbury and his Influence”, ss. 196-204; B. Pennington - „The Cistercians”, ss. 205-217; G.A. Zinn - „The Regular Canons", ss. 218-230). Wybitni pisarze tego okresu jak Anzelm z Canterbury 
czy Bernard Clairvaux byli wielkimi formatorami duchowości, która była praktykowana także w późniejszym średniowieczu. Precyzują oni drogę modlitwy, którą powinien kroczyć chrześcijanin. Zakon cystersów pokazuje, że rozwojowi duchowości sprzyja nie tylko asceza, ale także ręczna praca.

Druga część książki obejmuje dziewięć rozdziałów-artykułów. Pierwszy, autorstwa jednego z najbardziej znanych teologów prawosławnych J. Meyendorffa dotyczy soteriologii Kościoła Wschodniego („The Role of Christ. I. Christ as Saviour in the East", ss. 231-252). Autor przytacza doktrynę chrystologiczną dwóch greckich Ojców Kościoła: Atanazego i Cyryla Aleksandryjskiego, wskazując, że może ona stanowić wspólny mianownik, dla tradycji wschodniej i zachodniej. Artykuł ten uzupełnia prezentacja zachodniego punktu widzenia w wiekach X-XII na Osobę Chrystusa Odkupiciela ze zwróceniem uwagi na miejsce krzyża w pobożności chrześcijan na Zachodzie (B. McGinn „The Role of Christ. I. Chist as Savior in the West”, ss. 253-259).

Kolejny blok tematyczny stanowi trynitologia. Była ona - zdaniem autorów - esencjalną częścią życia i duchowości chrześcijan okresu patrystycznego. Konstytuowała treść modlitw, a także liturgię. Th. Hopko poddaje analizie doktrynę teologiczną u Ojców Kapadockich („The Trinity in the Cappadocians”, ss. 260-275), a M.T. Clark jej recepcję u pisarzy łacińskich: Mariusza Wiktoryna, Augustyna i Ryszarda od św. Wiktora (,The Trinity in Latin Christianity", ss. 276-290).

Wiara w Chrystusa, wcielonego Syna Bożego, stanowi fundament chrześcijańskiej antropologii. Koncentruje się ona na pojęciu osoby ludzkiej, uczynionej na obraz i podobieństwo Boga ( $\mathrm{Rdz} 1,26)$. W dalszej części książki przedstawione zostały linie wiodące antropologii chrześcijańskiej na Wschodzie i na Zachodzie (ss. 291-349). W chrześcijaństwie wschodnim (L. Thunberg - „The Human Person as Image of God. I. Eastern Christianity”, ss. 291-311) człowiek pojmowany jest jako mikrokosmos. Zgodnie z nauczaniem Ojców greckich, obraz Boga zawarty jest w duszy człowieka. Upodobnienie do Boga związane jest z procesem przebóstwienia. Jest ono paralelą do wcielenia Syna Bożego. Dzięki niemu człowiek może osiągnąć pełną komunię z Bogiem bez uwalniania się z ludzkiej natury. W chrześcijaństwie zachodnim (B. McGinn „The Human Person as Image of God. II. Western Christianity”, ss. 312-330) natomiast na plan pierwszy wybija się doktryna o łasce, którą Augustyn plasuje w centralnym miejscu antropologii. W kolejnym artykule J. Patout Burns wykazuje („Grace: the Augustinian Foundation”, ss. 331-349), że augustiańska doktryna o łasce zanurza stworzenie w Boskim pięknie. Łaska, bowiem jest obecnością Ducha Świętego, ponieważ jej podstawową formą jest miłość, która uzdalnia człowieka do kochania Boga i czynienia dobra.

W dalszej części książki wyakcentowany został związek liturgii z duchowością chrześcijańską („Liturgy and Spirituality”, ss. 350-381). Celebracja liturgiczna stanowi jej egzystencjalną część. W liturgii wschodniej (P. Meyendorff - 
„Eastern Liturgical Theology”, ss. 350-364) znajduje to swój szczególny wyraz w obrzędach sakramentu chrztu, w których w pełni wypowiada się doktryna o zamieszkiwaniu Ducha Świętego w człowieku. Analogicznie w celebracji Eucharystii, właśnie poprzez liturgię, chrześcijanin dochodzi do poznania Jezusa jako wcielonego Boga. Zdaniem autora, dzięki liturgii dochodzi do ujawnienia teocentryczności natury ludzkiej. Nie mniejszą witalnością cechuje się liturgia łacińska (P.M. Gy - „Sacraments and Liturgy in Latin Christianity”, ss. 365-381). Ukazany w niej jest eklezjalny wymiar sakramentów, szczególnie chrztu i Eucharystii. Autor mówi w związku z tym o eucharystycznej duchowości Augustyna, który głosi, że także ciało Kościoła karmione jest i formowane przez Eucharystię. Tematyka związku liturgii z duchowością chrześcijańską dopełniona została artykułem nt. kultu ikony (L. Ouspensky - „Icon and Art”, ss. 382-394), która jest liturgiczną formą sztuki. Kult ikony zatem nigdy nie może być utożsamiany z kultem sztuki.

W czterech ostatnich artykułach podjęta została tematyka praktycznej realizacji wskazań zawartych w teorii duchowości chrześcijańskiej. Najpierw omówione zostały praktyki modlitewne na Wschodzie, szczególnie w oparciu o dane Ojców Pustyni (K. Ware - „Ways of Prayer and Contemplation. I. Eastern", ss. 395-414). Droga od modlitwy ustnej do kontemplacji, droga do osiągnięcia hesychii naznaczona jest z jednej strony etapami umartwień i ascezy, z drugiej zaś strony realizowana stosunkowo łatwo dzięki praktykowaniu modlitwy Jezusowej, która stanowiła najpopularniejszą formę permanentnej łączności z Bogiem wśród mnichów. Analogicznie w duchowości zachodniej (J. Leclercq - „Ways of Prayer and Contemplation. II. Western”, ss. 415426) modlitwę (oratio) łączy się z lekturą Pisma Świętego (lectio). Obie te formy prowadzą do medytacji (meditatio). Osobne miejsce w duchowości zachodniej miało wspólne odmawianie officium divinum (brewiarz), w którym także było miejsce na czytanie i rozważanie tekstów biblijnych (lectio divina).

Jako realizacja teorii duchowości ukazane zostało także praktykowanie dziewictwa (P. Brown - „The Notion of Virginity in the Early Church”, ss. 427-443). Znane jest ono w Kościele od początku, a jego wzorem jest Maryja Dziewica. Do praktycznej realizacji teorii duchowości autorzy zaliczyli także kierownictwo duchowe (D. Corcoran - „Spiritual Guidance”, ss. 444-452). W początkach miało ono formę duchowego ojcostwa lub macierzyństwa. U Ojców Pustyni wyrażało się ono wskazaniami dotyczącymi poznania samego siebie i osiągania pokoju serca.

Całość kończy artykuł nt. życia religijnego świeckich chrześcijan w środowisku zachodnim (J. Fontaine - „The Practice of Christian Life: The Birth of the Laity", ss. 453-491). Autor podkreśla, że rozwijało się ono nie bez trudności, chociaż godnym odnotowania jest fakt, że spośród osób, które wcześniej pełniły urzędy świeckie wywodzą się najwybitniejsi mnisi, biskupi, a nawet papieże. 
Scharakteryzowana wyżej książka zawiera kompetentnie przedstawiony materiał z dziedziny historii duchowości chrześcijańskiej. Czytelnik otrzymuje wyczerpującą panoramę zarówno formowania się jak i przejawów duchowości chrześcijańskiej w ciągu pierwszych dwunastu wieków. Wysoką jakość merytoryczną książki zapewniają jej autorzy. Znajdują się wśród nich najwybitniejsi specjaliści o światowym znaczeniu, jak: J. Meyendorff, R.M. Grant, J. Gribomont, J.D. Zizioulas czy J. Leclercq. Sama lista autorów byłaby wystarczająca do przyznania książce najwyższej klasyfikacji.

Należy jednak zauważyć, że mimo, iż treść pochodzi od tak znanych autorów, książka napisana jest niezwykle przystępnym i zrozumiałym językiem. Nosi cechy klasycznego podręcznika akademickiego, a nie wysublimowanej rozprawy naukowej. Przypisy ograniczone są do niezbędnego minimum, a śródtytuły ułatwiają podążanie za prowadzoną myślą. Poszczególne artykuły noszą cechy syntezy, zawierającej najistotniejsze informacje $\mathrm{z}$ omawianego zagadnienia. Wysoka wartość merytoryczna książki idzie w parze z doskonałym ujęciem dydaktycznym. Może ona stanowić „instrumentum laboris” zarówno dla historyka jak i dla teologa.

Osobnym walorem książki jest jej wymiar ekumeniczny. Zaprezentowane w niej zostały różne tradycje duchowości: prawosławna, katolicka i protestancka. Czytelnik uzyskuje w ten sposób nie tylko w miarę pełny obraz duchowości chrześcijańskiej, ale także może znaleźć elementy, które służą wzajemnemu ubogaceniu poszczególnych tradycji.

Niewątpliwą zasługą tej edycji jest także odrzucenie negatywnych konotacji pojęcia „duchowość”, jakim ulega często współczesny człowiek. Duchowość chrześcijańska ukazana została nie jako pesymistyczna i antymaterialna wizja świata, lecz jako teocentryczna koncepcja obecności człowieka w świecie materialnym, gdzie także ciało powołane jest do komunii z Bogiem.

Biorąc pod uwagę powyższe dane uważam, że omawiana książka w pełni zasługuje na wydanie jej w tłumaczeniu polskim. Będzie ona doskonałym podręcznikiem zarówno dla studentów teologii jak i historii. Zakresem swoim obejmuje wielorakie przejawy duchowości nie tylko w sensie religijnym, ale także kulturowym i społecznym. Pozycji takiej brakuje na polskim rynku wydawniczym. Dotychczasowe podręczniki zawężone są do doktryny Ojców Kościoła (podręczniki patrologii), albo do przekroju historycznego całej doktryny teologicznej (podręczniki z historii teologii). Brakuje natomiast podręcznika, który przedstawiałby duchowość chrześcijańską pierwszych wieków, uwzględniając jej wymiar kulturowo - społeczny oraz różnorodność tradycji, którymi dzisiaj cechują się poszczególne wyznania chrześcijańskie. Interkonfesyjność podręcznika byłaby na polskim rynku wydawniczym osiągnięciem pionierskim.

Należy też dodać, że podręcznik duchowości chrześcijańskiej w pierwszych wiekach w ujęciu, w jakim mieści się recenzowana książka, byłby dobrą pomocą do realizacji programów nauczania, które obowiązują nie tylko na wy- 
działach teologii, ale także na wydziałach historii. Dla przykładu można podać, że Instytut Historii UAM przewiduje wykłady z zakresu myśli i duchowości chrześcijańskiej. Polska edycja omawianego podręcznika byłaby więc nieocenioną pomocą zarówno dla wykładowców, jak i dla studentów.

ks. Bogdan Częsz - Poznań, UAM

\section{ODPOWIEDŹ NA RECENZJĘ KS. L. GŁADYSZEWSKIEGO:}

Jerzy Andrzej WOJTCZAK-SZYSZKOWSKI, Fides et traditio. Wybór tekstów autorów wczesnego chrześcijaństwa (dla uczniów szkół katolickich, studentów i alumnów), Warszawa 2006, Drukarnia Archidiecezjalna w Katowicach, ss. 368 - VoxP 25 (2005) t. 48, 423-425.

Drogi Księże Doktorze! Pragnę odpowiedzieć na recenzję Ks. Doktora, bo w mym przekonaniu minęła się ona jednak z moimi intencjami i wymaga kilku uwag. Oto i one:

Książka Fides et traditio nie jest wydaniem naukowym tekstów pisarzy kościelnych, a jedynie wydaniem szkolnym (jak Ks. Doktor dobrze wie, jest bardzo wiele wydań szkolnych różnych autorów, nie tylko kościelnych), a jako wydanie szkolne nie jest zobowiązana do posiadania ani aparatu krytycznego, ani uczonych komentarzy, ani indeksów, ani wykresów, ani tabel i innych instrumentów wydania naukowego, a o tym, że jest wydaniem szkolnym, informuje napis na okładce, czyli najbardziej eksponowanej jej części, mówiący: „[...] dla uczniów szkół katolickich, studentów i alumnów”. Nie można zatem jej zarzucać, że nie posiada tego, czego nie obiecywała.

Po wtóre, gdy chodzi o zamieszczanie akcentów, to oprócz starych mszałów i brewiarzy, nie znam tekstów ani naukowych, ani szkolnych, w których byłyby znaczone akcenty: ich zaznaczanie byłoby wysoce niepedagogiczne, bo skłaniałoby uczących się do zaniechania kontaktu ze słownikiem i porzucenia myśli o doskonaleniu języka, a że akcentowanie to sprawa długa i żmudna, przekonany jestem po przeszło 40-letniej pracy na uniwersytecie, gdzie nawet studenci filologii klasycznej kończący już studia robią nieraz błędy w lekturze. Poza tym, musiałbym sam dokonać składu książki, bo powierzenie tego redaktorom mało lub wcale nie znającym języka, dałoby efekt odwrotny w postaci olbrzymiej liczby błędów w druku, co byłoby tylko katastrofą o fatalnych skutkach.

Po trzecie, koszty książki będącej wydaniem naukowym, zbliżałyby się do kosztów wydań zagranicznych, a przypomnę, że edycje niewielkich tylko pozycji patrystycznych na przykład w „Sources Chrétiennes” kształtują się średnio w cenie 30-40 EURO, ale są i liczne pozycje kilkakrotnie droższe. Znając możliwości finansowe naszych uczniów i studentów można być przekonanym, 